\title{
Enzymatic Defenses of the Mouse Heart Against Reactive Oxygen Metabolites
}

\author{
ALTERATIONS PRODUCED BY DOXORUBICIN
}

\author{
JAMES H. Doroshow, Gershon Y. LoCKer, and C. E. MYERS, Clinical Pharmacology \\ Branch, Division of Cancer Treatment, National Cancer Institute, Bethesda, \\ Maryland 20205
}

\begin{abstract}
A B S T R A C T The endogenous defenses of the mouse heart against reactive oxygen metabolites were investigated. The activities of three enzymes capable of detoxifying activated oxygen were determined in both the heart and liver; cardiac muscle contains 150 times less catalase and nearly four times less superoxide dismutase than liver. Glutathione peroxidase activities were, however, similar to the two tissues. Assay of glutathione peroxidase in the heart after 6 wk of selenium depletion with both hydrogen peroxide and cumene hydroperoxide as substrates revealed a $>80 \%$ drop in enzyme activity and gave no indication that murine cardiac tissue contains nonselenium-dependent glutathione peroxidase. The selenium-deficient state, which was characterized by markedly decreased cardiac glutathione peroxidase levels, led to significantly enhanced doxorubicin toxicity at a dose of 15 $\mathrm{mg} / \mathrm{kg}$ i.p.
\end{abstract}

Doxorubicin administration in selenium-sufficient animals resulted in a dose-dependent decrease in cardiac glutathione peroxidase activity; the decrease in enzyme activity lasted $72 \mathrm{~h}$ after $15 \mathrm{mg} / \mathrm{kg}$ i.p. In contrast, cardiac superoxide dismutase and hepatic superoxide dismutase and glutathione peroxidase were unaffected by this dose of doxorubicin.

These results suggest that the major pathway in cardiac tissue for detoxification of reactive oxygen metabolites is via the concerted action of superoxide

This work was presented in preliminary form at the 1978 Annual Meeting of the American Federation for Clinical Research, and an abstract pertaining to this work was published in 1978. Clin. Res. 26: 434A.

Dr. Doroshow's present address is Division of Medical Oncology, Department of Medicine, University of Southern California School of Medicine Los Angeles, Calif. Dr. Locker's present address is St. Joseph Hospital, Chicago, Ill.

Received for publication 8 January 1979 and in revised form 7 September 1979. dismutase and selenium-dependent glutathione peroxidase. The latter enzyme may be depleted by a selenium-deficient diet or doxorubicin treatment, leaving the heart with limited mechanisms for disposing of hydrogen peroxide or lipid peroxides.

\section{INTRODUCTION}

Doxorubicin is one of the most effective antineoplastic drugs in clinical practice (1). Its clinical usefulness extends from hematologic malignancies such as the acute leukemias and lymphomas to a wide range of solid tumors including breast, lung, and thyroid carcinoma (1). However, the use of this drug is complicated by cardiac toxicity that is often life-threatening and, to date, unexplained (2).

Although the mechanism of doxorubicin cardiac toxicity is unknown, several recent studies have demonstrated the conversion of doxorubicin to a free radical metabolite by cardiac mitochondria and by liver and cardiac microsomes $(3,4)$. This free radical metabolite has been shown to reduce molecular oxygen to superoxide anion and to initiate lipid peroxidation in vitro (5). In addition, the free radical scavenger, alpha tocopherol, can prevent the one electron reduction of oxygen by doxorubicin in these microsomal systems (6).

Parallel in vivo studies have shown that doxorubicin administration leads to lipid peroxidation in cardiac tissue and that this peroxidative process can be blocked by alpha tocopherol (7). Free radical scavengers have also proven effective in lessening the acute pathologic changes observed after doxorubicin treatment in mouse (7) and rat (8) heart as well as the chronic cardiomyopathic lesion in the rabbit (9).

One apparent paradox presented by these findings is that although the conversion of doxorubicin to a free radical metabolite is greater in hepatic compared to cardiac microsomal systems, only cardiac tissue de- 
velops clinically significant pathologic changes. It has been demonstrated, however, that although mammalian tissues normally possess the enzymatic apparatus to detoxify free radicals (superoxide dismutase, glutathione peroxidase, and catalase), alterations in the intracellular concentration of these protective enzymes can enhance tissue toxicity from drug-induced reactive oxygen species (10). Differential acute organ toxicity after doxorubicin might then be explained by the concentration of these defense enzymes in the heart and liver and the effect of the drug on their specific activities. We have examined the levels of superoxide dismutase (SOD), ${ }^{1}$ glutathione peroxidase, and catalase in these tissues. The results indicate that the heart, compared to the liver, has a much lower concentration of enzymatic defenses against free radical attack as well as a prolonged drug-related depression in cardiac glutathione peroxidase activity after exposure to doxorubicin.

\section{METHODS}

Experimental animals. $\mathrm{CDF}_{1}$ male mice were obtained at weaning from Dublin Laboratories, Dublin, Va. The animals were immediately placed on National Institutes of Health rat and mouse ration No. 5108 prepared by the Ralston Purina Co., St. Louis, Mo., were given tap water ad lib., housed in a constant $\left(22^{\circ} \mathrm{C}\right)$ temperature environment, and caged on hardwood bedding. The Ralston Purina diet that was used contained $0.33 \mathrm{ppm}$ of selenium, $80 \mathrm{IU} / \mathrm{kg}$ of alpha tocopherol, and used soybean and fish oil as major sources of fat. The selenium content of the diet was determined by atomic absorbance spectrometry by Dr. John Burke of the National Bureau of Standards, Washington, D. C. Experimental animals were used after $6 \mathrm{wk}$ on the defined diet. For studies of the effect of diet on cardiac glutathione peroxidase and doxorubicin toxicity, animals were fed the selenium-free and tocopherolfree Torula yeast and lard based diet of Rotruck et al. (11) to which had been added $100 \mathrm{IU} / \mathrm{kg}$ of tocopherol acetate and either no selenium or $1 \mathrm{ppm}$ selenium $/ \mathrm{kg}$ feed. These experimental animals were used after 6 or $12 \mathrm{wk}$ on the defined diets as indicated below. Defined selenium diets were obtained from ICN Nutritional Biochemicals Div., Cleveland, Ohio. These animals were given deionized, glass distilled water ad lib. and were similarly housed and caged.

Materials. Doxorubicin hydrochloride of clinical grade was obtained from the Investigational Drug Branch, Division of Cancer Treatment. In all experiments, doxorubicin hydrochloride for injection was prepared fresh with $0.85 \%$ sterile sodium chloride U. S. Pharmacopeia and was protected from light until used. NADPH type III, glutathione (reduced form), sodium azide, glutathione reductase type III, 1-epinephrine, bovine erythrocyte $\operatorname{SOD}(2,700 \mathrm{U} / \mathrm{mg}$ protein as assayed by the method of McCord and Fridovich [12]), Triton X-100, bovine albumin (fraction V), xanthine, xanthine oxidase (grade 1), and cytochrome $c$ (type VI from horse heart) were obtained from Sigma Chemical Co., St. Louis, Mo. $n$-butanol (spectral grade), methanol (spectral grade), silver nitrate, potassium cyanide, sodium chloride, sodium carbonate, mono- and dibasic sodium and potassium phosphate, potassium permanganate, and concentrated sulfuric acid (all American

\footnotetext{
'Abbreviation used in this paper: SOD, superoxide dismutase.
}

Chemical Society reagent grade), as well as ethyl alcohol (99\% pure) were purchased from Fisher Scientific Co., Fair Lawn, N. J. Hydrogen peroxide ( $30 \%$ solution) was obtained from Mallinckrodt Inc., St. Louis, Mo.; cumene hydroperoxide from ICN Pharmaceuticals, Inc., Life Sciences Group, Plainview, N. Y.; sucrose (density gradient grade) from Schwartz/ Mann Div., Becton, Dickinson \& Co., Orangeburg, N. Y.; EDTA from Aldrich Chemical Co., Inc., Milwaukee, Wis.; and Sephadex G-75 from Pharmacia Fine Chemicals, Piscataway, N. J. These compounds were obtained at the highest grade of purity and were used without further purification.

Survival of mice treated with doxorubicin. Mice were housed 25 to a cage and injected intraperitoneally at the same time of day with one of three doses of doxorubicin $(5,10$, and $15 \mathrm{mg} / \mathrm{kg}$ ) in a constant volume of saline. A total of 50 mice in each treatment group was followed for $10 \mathrm{wk}$ after injection to determine long-term as well as acute mortality from these doses.

Cardiac doxorubicin levels. Doxorubicin was assayed in cardiac tissue by modification of the fluorometric method of Schwartz (13) and Donelli et al. (14); this assay has been shown to reflect total drug content in tissue (13). To determine cardiac levels of doxorubicin, four experimental animals per time point were injected intraperitoneally with a doxorubicin dose of $15 \mathrm{mg} / \mathrm{kg}$ body wt. The same number of control animals received an equal volume of physiologic saline intraperitoneally. Experimental and control animals were killed by cervical dislocation; ventricles for cardiac doxorubicin levels were excised, trimmed of connective tissue, blotted dry, and the wet weight determined. Throughout the assay procedure each experimental sample, which consisted of the ventricular tissue from one mouse, was kept on ice and protected from light. The hearts were immediately washed free of erythrocytes in iced physiologic saline and then homogenized for $30 \mathrm{~s}$ at $4^{\circ} \mathrm{C}$ in $3 \mathrm{ml}$ of deionized, glass distilled water with a Brinkmann model PCU-2-110 Polytron (Brinkmann Instruments, Inc., Westbury, N. Y.). The homogenate was then processed as described (14). Relative fluorescent intensity was measured on a Perkin-Elmer model MPF-44A fluorescence spectrophotometer (Perkin-Elmer Corp., Instrument Div., Norwalk, Conn.) in ratio mode at an excitation wavelength of $470 \mathrm{~nm}$ and an emission wavelength of $585 \mathrm{~nm}$. Standard solutions of doxorubicin were prepared in concentrations from 5 to $5,000 \mathrm{ng} / \mathrm{ml} n$-butanol and these as well as tissue blanks from saline-treated controls were processed for each set of samples assayed. Sample homogenates from saline-treated controls to which a constant amount of doxorubicin $(10 \mu \mathrm{g})$ had been added as an internal standard were assayed to determine the extent of fluorescent quenching by tissue pigments; doxorubicin concentrations were adjusted to reflect this internal standardization. The relative fluorescence of the cardiac tissue blank was always less than the fluorescence of $1.0 \mathrm{ng}$ doxorubicin in $n$-butanol. Because the organic phase contained both unchanged doxorubicin and fluorescent metabolites (15), drug concentrations were expressed as nanograms doxorubicin equivalents per gram wet weight. The assay procedure was linear over the range of tissue concentrations from 250 to 5,000 neq doxorubicin/g with a maximum sensitivity of $50 \mathrm{neq} / \mathrm{g}$ heart. Cardiac doxorubicin determinations for experimental samples were performed in triplicate for each time period sampled.

Glutathione peroxidase. Glutathione peroxidase activity in mouse heart and liver was assayed by modification of the method of Paglia and Valentine (16), as used by Lawrence and Burk (17). Tissue was obtained from experimental and control animals as previously described; each heart muscle sample consisted of the pooled ventricular tissue of three mice; the left hepatic lobe was fragmented into 200 -mg repli- 
cates that were used to prepare a single sample for the determination of enzymatic activity. All tissues were vigorously washed in an iced solution of $0.25 \mathrm{M}$ sucrose, which contained $0.001 \mathrm{M}$ EDTA, to avoid contamination from erythrocyte enzymes (18); and then homogenized for $30 \mathrm{~s}$ at $4^{\circ} \mathrm{C}$ in $3 \mathrm{ml}$ of the sucrose-EDTA with the Brinkmann Polytron which had been kept on ice. The crude homogenate was centrifuged for $60 \mathrm{~min}$ at $105,000 \mathrm{~g}$ in a Beckman model L5-50 ultracentrifuge (Beckman Instruments, Inc., Palo Alto, Calif.) at $5^{\circ} \mathrm{C}$. The supernate was decanted at the end of ultracentrifugation and used directly to determine glutathione peroxidase activity. Preliminary experiments showed a linear relationship between supernatant protein added and enzyme activity measured.

To assess the degree of erythrocyte contamination in our $_{1}$ enzyme preparations, an aliquot of $105,000 \mathrm{~g}$ supernate was chromatographed on a Sephadex G-75 column $(2.5 \times 40 \mathrm{~cm})$ and erythrocyte hemoglobin was quantitated by dithionite reduction exactly as described (18). A total of $0.75 \mathrm{mg}$ of hemoglobin was detected, which accounted for $5 \%$ of the total protein in an enzyme sample.

Base-line cardiac and hepatic glutathione peroxidase activity was assessed in untreated animals. Where indicated, the experimental group received doxorubicin intraperitoneally. Enzyme activity in doxorubicin-treated animals was compared to simultaneously treated controls receiving physiologic saline.

Enzyme activities were determined as described (16) using a Gilford model 2400-2 recording spectrophotometer (Gilford Instrument Laboratories Inc., Oberlin, Ohio). The 1-ml reaction mixture contained $132 \mu \mathrm{mol}$ of phosphate buffer, $\mathrm{pH}$ $7.0,13.2 \mu \mathrm{mol}$ EDTA, $11.25 \mu \mathrm{mol}$ of sodium azide, $15 \mu \mathrm{mol}$ reduced glutathione, $0.84 \mu \mathrm{mol}$ NADPH, and $1 \mathrm{U}$ of glutathione reductase. After $100 \mu \mathrm{l}$ of the supernate was added to the reaction mixture, the enzymatic reaction was initiated with 220 nmol of hydrogen peroxide standardized by titanous chloride titration (19). Hydrogen peroxide was chosen as the substrate so that only the selenium-dependent glutathione peroxidase activity rather than the recently described nonseleniumdependent enzyme would be measured in our experimental samples (20). A sample blank contained all reagents except the enzyme preparation for which $100 \mu \mathrm{l}$ of the sucrose-EDTA solution was substituted. By subtracting the linear blank rate, which was consistently $<15 \%$ of that in enzyme-containing samples, all results were corrected for the nonenzymatic oxidation of NADPH by hydrogen peroxide. Furthermore, samples that contained either cardiac or hepatic enzyme preparations that had been boiled for 15 min under nitrogen showed no evidence of NADPH oxidation above that produced by $\mathrm{H}_{2} \mathrm{O}_{2}$ in the sample blanks. Each enzyme sample was assayed in triplicate, and a minimum of three experimental samples consisting of the pooled cardiac or hepatic tissue from nine mice were assayed for each determination of glutathione peroxidase activity. The data were expressed as nanomoles of NADPH oxidized to NADP per minute per milligram protein using the extinction coefficient for NADPH of $6.22 \times 10^{3} \mathrm{~mol}^{-1} \mathrm{~cm}^{-1}(21)$.

In experiments to determine the effect of dietary selenium on cardiac glutathione peroxidase, hearts from a representative group of weanling animals were assayed initially to establish base-line enzyme activity immediately before being placed on the selenium-free diet. Weanling animals were chosen because their tissue glutathione peroxidase levels provide a reproducible standard of comparison for further measurements that is not influenced by the subsequent effects of age or the selenium or tocopherol content of the diet. After $6 \mathrm{wk}$ on the experimental diet, glutathione peroxidase in heart muscle was determined again; 6 wk was chosen because preliminary observations revealed that at this time selenium-dependent glutathione peroxidase activity is depleted and remains depleted if the deficient diet is maintained. In these experiments, glutathione peroxidase activity was assayed with $220 \mathrm{nmol}$ of hydrogen peroxide and 880 nmol of cumene hydroperoxide (17). The cardiac enzyme activity assayed at $6 \mathrm{wk}$ with hydrogen peroxide or cumene hydroperoxide has been compared to the level at weaning determined with the corresponding substrate.

SOD. Cardiac and hepatic SOD activity was assessed by two different techniques. The method of Misra and Fridovich (22) depends upon the capacity of SOD to inhibit the autooxidation of epinephrine to adrenochrome at alkaline $\mathrm{pH}$. The standard ferricytochrome $c$ assay was also employed (18). To inhibit cytochrome $c$ oxidases, $\mathrm{KCN}(10 \mu \mathrm{M})$ was included in each assay (23).

Heart and liver samples were obtained and prepared as described for glutathione peroxidase except that iced $0.05 \mathrm{M}$ potassium phosphate buffer, $\mathrm{pH} 7.8$, which contained $100 \mu \mathrm{M}$ EDTA was used instead of sucrose-EDTA (18). In the epinephrine assay, a calibration curve was constructed for the inhibition of epinephrine auto-oxidation that was linear within the range of $0.1-10 \mu \mathrm{g}$ bovine SOD $/ \mathrm{ml}$ potassium phosphateEDTA. The protein concentration of the enzyme preparation assayed for SOD activity was adjusted to obtain $\sim 50 \%$ inhibition of the spontaneous rate of epinephrine oxidation. For cardiac tissue, 90-110 $\mu$ g protein were needed; for liver, 80-100 $\mu \mathrm{g}$ protein were employed. Once adjusted, these enzyme protein concentrations were held constant throughout the experimental procedure. Potassium phosphate-EDTA buffer, boiled commercial bovine erythrocyte SOD, and boiled cardiac and hepatic enzyme preparations used as blanks did not inhibit the auto-oxidation of epinephrine. The linear rate of oxidation in enzyme-containing samples was compared to the calibration curve and converted to SOD activity in units of micrograms SOD per milligram protein.

Cardiac and hepatic SOD were also assayed by the method of McCord and Fridovich $(12,18)$ as described by Marcus et al. (23) but without the addition of Triton X-100. In both assay systems, each sample was assayed in duplicate, and a minimum of three experimental enzyme samples from nine animals in each of the drug-treated and drug-free groups were used for the assessment of tissue SOD activity. The contribution of erythrocyte SOD to the measurement of the cardiac enzyme in these experiments was calculated to be $<0.1 \%$ (18). Tissue SOD was determined in untreated control animals. Enzyme activity in doxorubicin-treated animals was compared to simultaneously treated controls receiving physiologic saline.

Catalase. Catalase activity was assayed by the method of Cohen et al. (24). Cardiac and hepatic tissues were obtained as described for glutathione peroxidase. The ventricular tissue from three mice was pooled to prepare each cardiac catalase sample; a single left hepatic lobe constituted the tissue used for the hepatic catalase assay. Samples were vigorously washed free of erythrocytes and then processed as described (24). For cardiac tissue, the crude diluted enzyme as well as a 25-fold ( $\mathrm{vol} / \mathrm{vol}$ ) concentrate of the diluted enzyme prepared with an immersible molecular separator (PTGC $001 \mathrm{~K} 1$, Millipore Corp., Bedford, Mass.) were assayed for catalase activity; a sample that contained a boiled cardiac enzyme preparation, as well as one in which the order of addition of the $\mathrm{H}_{2} \mathrm{SO}_{4}$ and $\mathrm{H}_{2} \mathrm{O}_{2}$ was reversed, were used as blanks. Catalase activity was calculated from the first order rate constant $K=\log \left(S_{0} / S_{t}\right) \times 2.3 / t$, where $S_{0}$ is the initial substrate concentration, $S_{t}$ is the final substrate concentration, and $t$ is the reaction time $(3 \mathrm{~min})$. Catalase activity has been expressed as units that represent the calculated rate constant $(K)$ per milligram protein (25). 
To examine the possibility that cardiac catalase might be inactivated by the concentration of $\mathrm{H}_{2} \mathrm{O}_{2}$ employed in our assay, experiments were performed with a 1-min rather than 3-min incubation time, which has previously been shown to prevent alterations in tissue catalase activity (26). The effect of ethanol and Triton X-100 additions on cardiac catalase were also examined by sequential incubations in a manner similar to that performed by Cohen et al. (24) for the hepatic enzyme. As a final check of tissue catalase levels, we measured catalase activity in the heart and liver by an alternate technique (27) with enzyme levels expressed as Sigma units per milligram protein.

Five experimental heart and liver samples from a total of 30 mice were each assayed in triplicate by both assays to determine cardiac and hepatic catalase activity.

Protein determination. Enzyme proteins were determined by the method of Lowry et al. (28) with crystalline bovine albumin as the standard.

Statistics. Data were analyzed with the two-tailed Student's $t$ test for independent means (NS, $P>0.05$ [29]). Survival data were compared by the log rank test (30). Data are expressed as the mean $\pm 1 \mathrm{SE}$.

\section{RESULTS}

Animal survival. A dose-response curve was generated for intraperitoneal doxorubicin in these studies. At $5 \mathrm{mg} / \mathrm{kg}, 49$ of $50 \mathrm{mice}$ were alive at $10 \mathrm{wk}$. With a dose of $10 \mathrm{mg} / \mathrm{kg}, 40$ out of 50 animals were alive at $10 \mathrm{wk} ; 15 \mathrm{mg} / \mathrm{kg}$ doxorubicin increased mortality further, as 28 of 50 mice survived for $10 \mathrm{wk}$. Most animals in the high-dose groups died within the first $2 \mathrm{wk}$; however, animals continued to die through the 8th wk after injection. Because the doses chosen for these studies resulted in a wide range of observed mortality and because pathologic lesions have been demonstrated in the heart after $15 \mathrm{mg} / \mathrm{kg}$ doxorubicin (7), we chose the same dosage range of doxorubicin for the remainder of our experiments.

Cardiac uptake of doxorubicin. Though intraperitoneal injection has been a frequent means of treating experimental murine ascites tumors (31), the cardiac uptake of doxorubicin after intraperitoneal administration has not been frequently reported (32). Because experiments reported in this and previous studies demonstrating cardiac lipid peroxidation employed intraperitoneal doxorubicin (7), it was necessary to document the tissue pharmacokinetics of the drug when administered by this route. As shown in Fig. 1, there is rapid uptake of doxorubicin into the heart after intraperitoneal injection. Tissue concentrations of the drug are easily measurable at $30 \mathrm{~min}(2,520 \pm 170 \mathrm{ng} / \mathrm{g}$, mean \pm 1 SEM $)$ and $1 \mathrm{~h}(2,690 \pm 320 \mathrm{ng} / \mathrm{g})$ after injection of $15 \mathrm{mg} / \mathrm{kg}$. Peak doxorubicin concentration has been reached at $3 \mathrm{~h}(3,110 \pm 100 \mathrm{ng} / \mathrm{g})$ with a steady, if prolonged, disappearance thereafter. Cardiac drug levels at 18 and $24 \mathrm{~h}(1,635 \pm 40 \mathrm{ng} / \mathrm{g} ; 1,747 \pm 190 \mathrm{ng} / \mathrm{g})$ are substantial; doxorubicin-derived fluorescence is still measurable $48 \mathrm{~h}$ after injection $(925 \pm 130 \mathrm{ng} / \mathrm{g})$.

Distribution of enzymatic defenses. The specific

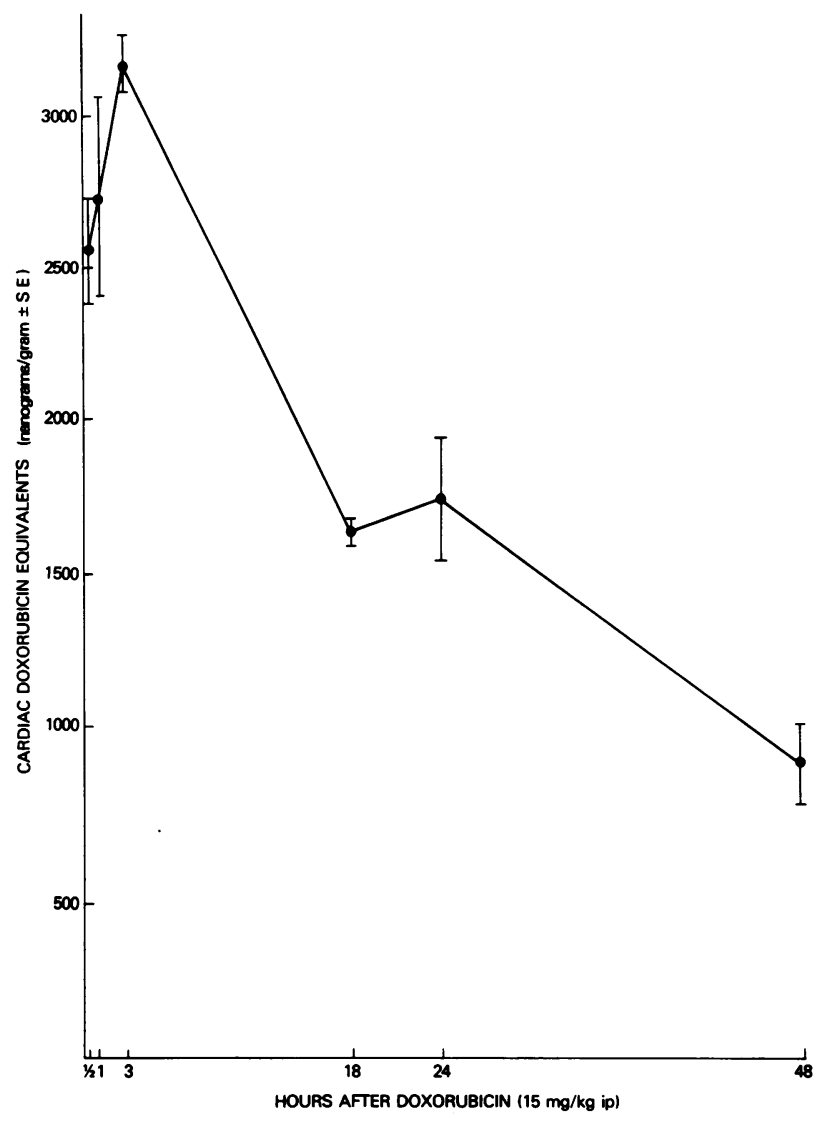

FigURE 1 Cardiac doxorubicin concentration after intraperitoneal administration. Animals received doxorubicin 15 $\mathrm{mg} / \mathrm{kg}$ i.p. and cardiac doxorubicin levels were followed for $48 \mathrm{~h}$ after the dose. Each time point represents the mean $\pm S E$ of four experiments.

activities of catalase, SOD, and glutathione peroxidase have been principally examined in the erythrocyte (33) and the rat lung (34) and liver (35). A comparison of the enzymatic activities of these enzymes in heart and liver in a single species has not been reported.

Catalase activity (mean \pm 1 SEM) in mouse liver was $173.3 \pm 10.5 \mathrm{U}$; cardiac catalase was $1.1 \pm 0.4 \mathrm{U}$, or $<0.6 \%$ of that found in the liver, $P<0.001$. To insure that Triton X-100 or ethanol added during the assay procedure did not inactivate cardiac catalase, enzyme activities were determined for heart samples before and after the sequential addition of these agents. The use of ethanol resulted in a $21.3 \%$ increase in enzyme activity; the further addition of Triton X-100 yielded a cumulative increase in cardiac catalase levels of $26.3 \%$, which was significantly greater than untreated samples, $P<0.05$. To assure that the concentration of $\mathrm{H}_{2} \mathrm{O}_{2}$ used in our assay system $(6 \mathrm{mM})$ did not convert cardiac catalase to the poorly catalytic compound III, experiments were performed with a 1-min rather than a 3-min $\mathrm{H}_{2} \mathrm{O}_{2}$ incubation. Del Río et al. (26) have shown 
that a 1-min incubation with $\mathrm{H}_{2} \mathrm{O}_{2}$ concentrations greater than those used in our study do not alter catalase activity. In such experiments, we confirmed that the heart has $<1.3 \%$ the catalase activity of the liver, $P<0.02$. Finally, when the catalase levels in the two tissues are compared by a different assay procedure (27), we found (mean \pm 1 SEM) $2,612 \pm 239$ Sigma U of catalase activity per milligram protein in liver compared to $4.05 \pm 0.15$ Sigma U/mg protein in heart.

The activity of cardiac SOD was also significantly lower than that of the liver enzyme. SOD in heart (mean \pm 1 SEM; $9.7 \pm 0.9 \mu \mathrm{g} / \mathrm{mg}$ ) was $27.1 \%$ that in liver $(35.8$ $\pm 2.3 \mu \mathrm{g} / \mathrm{mg}), P<0.001$ when assayed by the epinephrine auto-oxidation method; with the cytochrome $c$ reduction assay, cardiac SOD $(7.21 \pm 0.42 \mu \mathrm{g} / \mathrm{mg})$ was $43 \%$ of that found in the liver $(16.6 \pm 1.12 \mu \mathrm{g} / \mathrm{mg}), P<0.01$.

Selenium-dependent (17) cardiac glutathione peroxidase activity (mean \pm 1 SEM; $55.6 \pm 1.2 \mathrm{nmol} \mathrm{NADPH}$ oxidized/min per $\mathrm{mg}$ ) was not significantly different from that of the hepatic enzyme $(64.4 \pm 6.7 \mathrm{nmol}$ NADPH oxidized/min per $\mathrm{mg}$ ). Thus, cardiac tissue, in contrast to liver, has appreciably less of two of the three enzymes known to be involved in the detoxification of reactive oxygen species and the removal of intracellular peroxide.

Effect of selenium deficiency on cardiac glutathione peroxidase. The use of cumene hydroperoxide as the substrate in the glutathione peroxidase assay measures the activities of both the selenium and nonseleniumdependent forms of the enzyme; whereas the use of hydrogen peroxide measures the selenium-dependent enzyme activity only. Thus, if an appreciable amount of the nonselenium-dependent enzyme is present, selenium deficiency should lead to a greater drop in glutathione peroxidase activity when measured with hydrogen peroxide as compared to cumene hydroperoxide as substrate. We found that cardiac glutathione peroxidase activity is markedly diminished by selenium deficiency. After $6 \mathrm{wk}$ on the selenium-free diet, glutathione peroxidase in the heart was (percent control $\pm 1 \mathrm{SE}$ ) $18 \pm 2 \%$ of the enzyme level found in weanlings when hydrogen peroxide was used as substrate and $17 \pm 2 \%$ of control when cumene hydroperoxide was employed. These results confirm that the glutathione peroxidase measured is dependent upon dietary selenium. Furthermore, the similarity in the results obtained with both cumene hydroperoxide and hydrogen peroxide as substrates suggests an absence of the nonselenium-dependent enzyme.

Effect of selenium deficiency on doxorubicin toxicity. In experiments to examine the effect of variations in tissue glutathione peroxidase on doxorubicin toxicity, animals were raised for $12 \mathrm{wk}$ on the seleniumsufficient and selenium-deficient diets. At this time cardiac glutathione peroxidase activity in the seleniumdeficient animals, assayed with $\mathrm{H}_{2} \mathrm{O}_{2}$, was (mean \pm 1
SE) $13.7 \pm 1.6 \%$ that in the selenium-sufficient group. Glutathione peroxidase-deficient mice treated with 15 $\mathrm{mg} / \mathrm{kg}$ i.p. doxorubicin had an $11 \mathrm{~d}$ median and $0 \% 10$ wk survival $(n=20)$. Animals raised on the seleniumcontaining diet $(n=20)$ survived significantly longer, with a median survival of $26 \mathrm{~d}$ and a long-term survival of $40 \%$ after the same dose of doxorubicin, $P<0.01$.

Effect of doxorubicin on glutathione peroxidase. Since the distribution studies of free radical defense enzymes in heart and liver and the toxicity experiments in selenium-deficient animals suggested that glutathione peroxidase may play an especially important role in protecting the heart from peroxidative attack, the effect of doxorubicin on the selenium-dependent cardiac enzyme was assessed. A single dose of doxorubicin $(15 \mathrm{mg} / \mathrm{kg}$ ) caused an acute depression in glutathione peroxidase activity. $24 \mathrm{~h}$ after injection, cardiac enzyme levels were $<44 \%$ of control (Table I). Significantly diminished activity in animals treated with doxorubicin compared to simultaneous saline controls persisted for 48 and $72 \mathrm{~h}$ after the dose. The drop in cardiac enzyme activity that was not evident $4 \mathrm{~h}$ after doxorubicin had returned to control level by $96 \mathrm{~h}$ after the dose.

The effect of doxorubicin on glutathione peroxidase was found to be dependent upon the dose of drug administered. A significant but lesser decrease in glutathione peroxidase activity was noted at $10 \mathrm{mg} / \mathrm{kg}$ with no apparent change after $5 \mathrm{mg} / \mathrm{kg}$ doxorubicin (Table I).

To assess the specificity of the observed change in cardiac glutathione peroxidase, hepatic enzyme activity was measured after doxorubicin. $24 \mathrm{~h}$ after treatment with $15 \mathrm{mg} / \mathrm{kg}$, glutathione peroxidase activity in the liver was unchanged from control values (Table I).

Because there is a considerable concentration of doxorubicin remaining in the heart $24 \mathrm{~h}$ after administration (Fig. 1), the effect of $10 \mu \mathrm{M}$ doxorubicin on the reaction mixture was assessed. At this concentration (which exceeds the peak doxorubicin level achieved in the heart after a $15 \mathrm{mg} / \mathrm{kg}$ dose) doxorubicin added directly to the reaction mixture had no effect on the measurement of enzyme activity.

To determine whether doxorubicin metabolites might be affecting the glutathione peroxidase assay, the activity of a one-to-one ( $\mathrm{vol} / \mathrm{vol}$ ) mixture of cardiac or hepatic enzyme samples from drug-treated and drugfree animals was determined. The glutathione peroxidase activity of this mixture $(n=3)$ was statistically identical to the arithmetic mean of the peroxidase levels from doxorubicin-treated and saline-treated animals, suggesting that drug metabolites did not interfere with assay conditions.

Effect of doxorubicin on SOD. Though glutathione peroxidase acts to detoxify peroxides, protection against superoxide anion is afforded by SOD (36). The effect of doxorubicin on cardiac SOD was determined 
TABLE I

Effect of Doxorubicin on Glutathione Peroxidase*

\begin{tabular}{|c|c|c|c|c|c|c|}
\hline \multirow[b]{2}{*}{ Organ } & \multirow{2}{*}{$\begin{array}{l}\text { Doxorubicin } \\
\text { dose }\end{array}$} & \multicolumn{5}{|c|}{ Hours after doxorubicin treatment } \\
\hline & & 4 & 24 & 48 & 72 & 96 \\
\hline & $m g / k g$ i.p. & & & & & \\
\hline \multirow[t]{3}{*}{ Heart } & 5 & & $\begin{array}{l}93 \pm 9 \\
(\mathrm{NS})\end{array}$ & & & \\
\hline & 10 & & $\begin{array}{c}63 \pm 6 \\
(P<0.02)\end{array}$ & & & \\
\hline & 15 & $\begin{array}{c}104 \pm 13 \\
(\mathrm{NS})\end{array}$ & $\begin{array}{c}43.9 \pm 4.4 \\
(P<0.01)\end{array}$ & $\begin{array}{c}77 \pm 2 \\
(P<0.05)\end{array}$ & $\begin{array}{c}53 \pm 7 \\
(P<0.05)\end{array}$ & $\begin{array}{l}84 \pm 8 \\
\text { (NS) }\end{array}$ \\
\hline Liver & 15 & & $\begin{array}{c}113 \pm 9 \\
(\mathrm{NS})\end{array}$ & & & \\
\hline
\end{tabular}

$P$, values of Student's $t$ test.

* Glutathione peroxidase activity in doxorubicin-treated animals compared to simultaneous controls receiving physiologic saline, percent control $\pm 1 \mathrm{SE}$.

after a dose of $15 \mathrm{mg} / \mathrm{kg}$. At $4 \mathrm{~h}$ (percent control $\pm 1 \mathrm{SE}$; $113 \pm 15 \%), 24 \mathrm{~h}(131 \pm 19 \%), 48 \mathrm{~h}(117 \pm 27 \%), 72 \mathrm{~h}$ $(83 \pm 15 \%)$, and $96 \mathrm{~h}(94 \pm 15 \%)$ after the drug, there were no significant changes in enzyme activity. At the same dose, hepatic SOD $(76 \pm 6 \%)$ was also insignificantly different from control. A cuvette concentration of $10 \mu \mathrm{M}$ doxorubicin did not alter the spontaneous auto-oxidation of epinephrine to adrenochrome at alkaline $\mathrm{pH}$; neither did this concentration block the inhibition of epinephrine auto-oxidation at $30^{\circ} \mathrm{C}$ by $1 \mu \mathrm{g}$ of bovine erythrocyte SOD added to the reaction mixture.

To confirm these findings, cardiac and hepatic SOD activity $24 \mathrm{~h}$ after doxorubicin ( $15 \mathrm{mg} / \mathrm{kg}$ i.p.) was examined by the cytochrome $c$ technique. Cardiac and hepatic SOD in drug-treated animals was, respectively, (mean $\pm 1 \mathrm{SE}$ ) $110 \pm 14$ and $97.7 \pm 7.3 \%$ of that in controls receiving physiologic saline, NS. SOD activity in a oneto-one ( $\mathrm{vol} / \mathrm{vol}$ ) mixture of cardiac enzyme samples from doxorubicin- and saline-treated animals was insignificantly different from the enzyme activity of either sample alone. When $0.25 \mu \mathrm{g}$ of commercially prepared SOD was added as an internal standard to the cardiac enzyme preparation at the time of tissue homogenization, the increase in measured SOD activity was identical in enzyme samples from both drug- and saline-treated animals. These experiments indicate that doxorubicin metabolites did not interfere with the SOD assay as performed.

\section{DISCUSSION}

The development of selective, cumulative damage to the heart after doxorubicin administration requires a unique interaction between the drug and cardiac tissue.
If doxorubicin augments the production of oxygen metabolites in vivo, then the disposition of those metabolites may be an important determinant of tissue injury. In this and other studies (7), we have demonstrated that the heart has limited defenses against the toxic effects of peroxides, especially when compared to the liver, an organ also known to activate doxorubicin to a free radical metabolite.

Aebi and Wyss (37) and Fridovich (36) have suggested that catalase, SOD, and glutathione peroxidase function in unison to prevent cell damage from reactive oxygen radicals. Our experiments show that heart muscle, compared to liver, contains very little catalase. In a recent study, the same observation was made for rat and rabbit heart (3). These results strongly suggest that glutathione peroxidase, and not catalase, represents the major enzymatic route of hydrogen peroxide detoxification in the heart.

The heart also contains far less SOD than the liver. This has been reported for rats (38) as well as man (39). Thus, in the presence of heightened superoxide production from doxorubicin, the relative lack of SOD in the heart compared to the liver may increase the chance of cardiac muscle damage from reactive oxygen.

We have also examined cardiac tissue for a third enzyme capable of preventing peroxidative injury. Mouse heart has little, if any, nonselenium-dependent glutathione peroxidase. These results agree with a recent report by Lawrence and Burk (40) in rat heart, and underscore the importance of the selenium-containing peroxidase.

Because of the relative lack of cardiac antioxidant enzymes, selenium-containing glutathione peroxidase provides a major enzymatic pathway for the removal of active oxygen metabolites from the heart. Many other 
studies have demonstrated that glutathione peroxidase catalyzes the decomposition of lipid peroxides and hydrogen peroxide to nontoxic alcohols or water, respectively (16). Recently, McCay et al. (41) have shown that glutathione peroxidase may exert its effect by directly preventing free radical attack on polyunsaturated membrane lipids. These results led us to perform experiments that demonstrate that selenium deficiency, with a concomitant decrease in cardiac glutathione peroxidase, markedly augments doxorubicin toxicity, perhaps because of unchecked lipid peroxidation. Thus, glutathione peroxidase may play an important role in the prevention of free radical damage to the heart from doxorubicin.

The depression in glutathione peroxidase activity that we observed for $72 \mathrm{~h}$ after a single dose of doxorubicin further impairs the heart's defenses against free radical attack, and increases the likelihood of cardiac damage from reactive oxygen metabolites. Though the specificity of this result has not been conclusively documented, doxorubicin administration had no apparent effect on SOD activity in the heart or liver, or on hepatic glutathione peroxidase. Under these circumstances, it seems less likely that the decrease in enzyme activity could be due exclusively to inhibition of protein synthesis by doxorubicin (42), unless the turnover of the cardiac enzyme is much more rapid than that in the liver.

There are several other possible explanations for the drop in cardiac glutathione peroxidase that we found. Wills has shown that lipid peroxides may inhibit the activity of selected enzymes, probably by oxidation of reduced thiol groups (43). Though glutathione peroxidase is known to contain reduced thiols (44), the enzyme can use a wide range of lipid peroxides as substrates, which makes this explanation improbable.

Another possible explanation for our finding of decreased glutathione peroxidase activity after doxorubicin is oxidative damage to the enzyme. Rister and Baehner (45) have demonstrated that incubation of glutathione peroxidase in vitro with a source of superoxide anion will significantly diminish enzyme activity. The selenocysteine molecule, felt to be at the active site of glutathione peroxidase (46), can be oxidized to a diselenide that is resistant to reduction. Thus, a doxorubicin free radical metabolite, or activated oxygen radicals that it may generate, could be directly responsible for the decrease in enzyme activity we measured. Alternatively, malondialdehyde, a by-product of lipid peroxidation that has been demonstrated in cardiac tissue after doxorubicin (7), may also diminish enzyme activity by oxidizing the active site or by forming protein cross-links (47). The results of other studies showing that alpha tocopherol limits the oxidation of intracellular selenium (48) and prevents malondialdehyde formation in the heart after doxorubicin (7) support an oxidative mechanism for the observed decrease in cardiac glutathione peroxidase. Thus, it may be because the heart lacks a full complement of antioxidant enzymes that the glutathione peroxidase system itself is at risk from oxygen metabolites. Further studies into these possible mechanisms are in progress.

In the heart, where glutathione peroxidase is a major enzymatic mechanism for the disposal of peroxides, a prolonged depression in the level of this enzyme might lead to intracellular peroxide accumulation. If doxorubicin increases cardiac superoxide anion generation; the potential exists for hydrogen peroxide formation at a time when peroxide removal is impaired; a hydrogen peroxide concentration could then be reached that would exceed the detoxifying ability of the myocardial cell (3).

In summary, doxorubicin may damage the heart because its administration leads to free radical production (6) at the same time that it abrogates a major intracellular defense against free radical attack.

\section{REFERENCES}

1. Carter, S. K. 1975. Adriamycin-a review. J. Nat. Cancer Inst. 55: 1265-1274.

2. Lenaz, L., and J. A. Page. 1976. Cardiotoxicity of adriamycin and related anthracyclines. Cancer Treat. Rev. 3: 111-120.

3. Thayer, W. S. 1977. Adriamycin stimulated superoxide formation in submitochondrial particles. Chem. Biol. Interact. 19: 265-278.

4. Bachur, N. R., S. L. Gordon, and M. V. Gee. 1978. A general mechanism for microsomal activation of quinone anticancer agents to free radicals. Cancer Res. 38: 17451750 .

5. Goodman, J., and P. Hochstein. 1977. Generation of free radicals and lipid peroxidation by redox cycling of adriamycin and daunomycin. Biochem. Biophys. Res. Commun. 77: 797-803.

6. Bachur, N. R., S. L. Gordon, and M. V. Gee. 1977. Anthracycline antibiotic augmentation of microsomal electron transport and free radical formation. Mol. Pharmacol.13: 901-910.

7. Myers, C. E., W. P. McGuire, R. H. Liss, I. Ifrim, K. Grotzinger, and R. C. Young. 1977. Adriamycin: the role of lipid peroxidation in cardiac toxicity and tumor response. Science (Wash. D. C.). 197: 165-167.

8. Sonneveld, P. 1978. Effect of $\alpha$-tocopherol on the cardiotoxicity of adriamycin in the rat. Cancer Treat. Rep. 62: 1033-1036.

9. Van Vleet, J. F., L. Greenwood, V. J. Ferrans, and A. H. Rebar. 1978. Effect of selenium-vitamin $\mathrm{E}$ on adriamycininduced cardiomyopathy in rabbits. Am. J. Vet. Res. 39: 997-1010.

10. Omaye, S. T., K. A. Reddy, and C. E. Cross. 1978. Enhanced lung toxicity of paraquat in selenium-deficient rats. Toxicol. Appl. Pharmacol. 43: 237-247.

11. Rotruck, J. T., A. L. Pope, H. E. Ganther, and W. G. Hoekstra. 1972. Prevention of oxidative damage to rat erythrocytes by dietary selenium. J. Nutr. 102: 689-696.

12. McCord, J. M., and I. Fridovich. 1969. Superoxide dismutase-an enzymatic function for erythrocuprein (hemocuprein). J. Biol. Chem. 244: 6049-6055.

13. Schwartz, H.S. 1973. A fluorometric assay for daunomycin and adriamycin in animal tissues. Biochem. Med. 7: 396-404. 
14. Donelli, M. G., A. Martini, T. Colombo, A. Bossi, and S. Garattini. 1976. Heart levels of adriamycin in normal and tumor-bearing mice. Eur. J. Cancer 12: 913-923.

15. Benjamin, R. S., C. E. Riggs, Jr., and N. R. Bachur. 1977. Plasma pharmacokinetics of adriamycin and its metabolites in humans with normal hepatic and renal function. Cancer Res. 37: 1416-1420.

16. Paglia, D. E., and W. N. Valentine. 1967. Studies on the quantitative and qualitative characterization of erythrocyte glutathione peroxidase. J. Lab. Clin. Med. 70: 158169.

17. Lawrence, R. A., and R. F. Burk. 1976. Glutathione peroxidase activity in selenium-deficient rat liver. Biochem. Biophys. Res. Commun. 71: 952-958.

18. Keele, B. B., J. M. McCord, and I. Fridovich. 1971. Further characterization of bovine superoxide dismutase and its isolation from bovine heart. J. Biol. Chem. 246: 28752880.

19. Egerton, A. C., A. J. Everett, G. J. Minkoff, S. Rudrakanchana, and K. C. Salooja. 1954. The analysis of combustion products. I. Some improvements in the methods of analysis of peroxides. Analytica Chimica Acta. 10: $422-428$.

20. Burk, R. F., K. Nishiki, R. A. Lawrence, and B. Chance. 1978. Peroxide removal by selenium-dependent and selenium-independent glutathione peroxidases in hemoglobin-free perfused rat liver. J. Biol. Chem. 253: 43-46.

21. Horecker, B. L., and A. Kornberg. 1948. The extinction coefficients of the reduced band of pyridine nucleotides. J. Biol. Chem. 175: 385-390.

22. Misra, H. P., and I. Fridovich. 1972. The role of superoxide anion in the autoxidation of epinephrine and a simple assay for superoxide dismutase. J. Biol. Chem. 247: $3170-3175$.

23. Marcus, A. J., S. T. Silk, L. B. Safier, and H. L. Ullman. 1977. Superoxide production and reducing activity in human platelets. J. Clin. Invest. 59: 149-158.

24. Cohen, G., D. Dembiec, and J. Marcus. 1970. Measurement of catalase activity in tissue extracts. Anal. Biochem. 34: $30-38$.

25. Aebi, H. 197.4. Catalase. In Methods of Enzymatic Analysis. H. U. Bergmeyer, editor. Academic Press, Inc., New York. 2nd edition. 2: 673-684.

26. Del Río, L. A., M. G. Ortega, A. L. López, and J. L. Gorgé. 1977. A more sensitive modification of the catalase assay with the clark oxygen electrode. Anal. Biochem. 80: 409-415.

27. Sigma Chemical Co. 1978. Biochemical and Organic Compounds for Research. St. Louis, Mo. 150.

28. Lowry, O., N. J. Rosebrough, A. L. Farr, and R. J. Randall. 1951. Protein measurement with the Folin phenol reagent. J. Biol. Chem. 193: 265-275.

29. Armitage, P. 1971. Statistical Methods in Medical Research. Blackwell Scientific Publications Ltd., Oxford, England. 104-126.

30. Mantel, N. 1966. Evaluation of survival data and two new rank order statistic's arising in its consideration. Cancer Chemother. Rep. 50: 163-170.

31. Goldin, A., and R. K. Johnson. 1975. Experimental tumor activity of adriamycin (NSC-123127). Cancer Chemother. Rep. Part.III. 6: $137-145$.
32. Bachur, N. R., R. C. Hildebrand, and R. S. Janke. 1974. Adriamycin and daunorubicin disposition in the rabbit. J. Pharmacol. Exp. Ther. 191: 331-340.

33. Maral, J., K. Puget, and A. M. Michelson. 1977. Comparative study of superoxide dismutase, catalase and glutathione peroxidase levels in erythrocytes of different animals. Biochem. Biophys. Res. Commun. 77: 15251535.

34. Stevens, J. B., and A. P. Autor. 1977. Induction of superoxide dismutase by oxygen in neonatal rat lung. J. Biol. Chem. 252: 3509-3514.

35. Oshino, N., and B. Chance. 1977. Properties of glutathione release observed during reduction of organic hydroperoxide, demethylation of aminopyrine and oxidation of some substances in perfused rat liver, and their implications for the physiological function of catalase. Biochem. J. 162: 509-525.

36. Fridovich, I. 1978. The biology of oxygen radicals. Science (Wash. D. C.). 201: 875-880.

37. Aebi, H. E., and S. R. Wyss. 1978. Acatalasemia. In The Metabolic Basis of Inherited Disease. J. B. Stanbury, J. B. Wyngaarden, and D. S. Fredrickson, editors. McGraw-Hill Book Co., New York. 4th edition. 17921807.

38. Van Hien, P., K. Kovács, and B. Matkovics. 1975. Properties of enzymes. II. Comparative study of superoxide dismutase activity in rat tissues. Enzyme (Basel). 19: 1-4.

39. Beckman, G., E. Lundgren, and A. Tärnvik. 1973. Superoxide dismutase isozymes in different human tissues, their genetic control and intracellular localization. Hum. Hered. 23: 338-345.

40. Lawrence, R. A., and R. F. Burk. 1977. Species and tissue distribution of non selenium-dependent glutathione peroxidase activity. Fed. Proc. 36: 1095. (Abstr.)

41. McCay, P. B., D. D. Gibson, K. Fong, and K. R. Hornbrook. 1976. Effect of glutathione peroxidase on lipid peroxidation in biological membranes. Biochem. Biophys. Acta. 431: 459-468.

42. Wang, J. J., D. S. Chervinsky, and J. M. Rosen. 1972. Comparative biochemical studies of adriamycin and daunomycin in leukemic cells. Cancer Res. 32: 511-515.

43. Wills, E. D. 1961. Effect of unsaturated fatty acids and their peroxides on enzymes. Biochem. Pharmacol. 7: $7-16$.

44. Awasthi, Y. C., E. Beutler, and S. K. Srivastava. 1975. Purification and properties of human erythrocyte glutathione peroxidase. J. Biol. Chem. 250: 5144-5149.

45. Rister, M., and R. L. Baehner. 1976. The alteration of superoxide dismutase, catalase, glutathione peroxidase, and $\mathrm{NAD}(\mathrm{P}) \mathrm{H}$ cytochrome $c$ reductase in guinea pig polymorphonuclear leukocytes and alveolar macrophages during hyperoxia. J. Clin. Invest. 58: 1174-1184.

46. Tappel, A. L., J. W. Forstrom, J. J. Zakowski, D. E. Lyons, and W. C. Hawkes. 1978. The catalytic site of rat liver glutathione peroxidase as selenocysteine and selenocysteine in rat liver. Fed. Proc. 37: 706. (Abstr.)

47. Chio, K. S., and A. L. Tappel. 1969. Inactivation of ribonuclease and other enzymes by peroxidizing lipids and by malonaldehyde. Biochemistry. 8: 2827-2832.

48. Diplock, A. T., H. Baum, and J. A. Lucy. 1971. The effect of vitamin $\mathrm{E}$ on the oxidation state of selenium in rat liver. Biochem. J. 123: 721-729. 